\title{
Comparison Effectiveness Breast Milk and Dry Sterile Gauze to Treatment Umbilical Cord
}

\author{
Aris Hartono, Nasrul Hadi Purwanto \\ Department of Nursing, STIKES Dian Husada, Mojokerto, Indonesia \\ Email: arishartono@dianhusada.ac.id
}

Received 2 December 2015; accepted 15 February 2016; published 18 February 2016

Copyright (C) 2016 by authors and Scientific Research Publishing Inc.

This work is licensed under the Creative Commons Attribution International License (CC BY). http://creativecommons.org/licenses/by/4.0/

(c) (i) Open Access

\begin{abstract}
Infection of the umbilical cord has been the cause of illness and death constantly in different countries. Each year 500,000 infants die from neonatal tetanus and 460,000 infants die from bacterial infections. One way that is currently being developed is the use breast milk. Various kinds of content of nutrients and substances that exist in breast milk may reduce the risk of incidence of the infection so that the baby can avoid the incidence of umbilical cord infection. This type of research is quasy experiments with static group comparison. The research data are obtained by researchers using observation sheet, then the data are tabulated. Results of the observation of the time required in the treatment of breast milk and umbilical cord using dry Sterile gauze then compare and conclusions draw an average release time of each media. From the results, the average time of the release of the umbilical cord using breast milk is for $\mathbf{1 2 7 . 4 1}$ hours and the average time of the release of the umbilical cord using dry Sterile gauze is for 157.38 hours. From the results of correlation Mann Whitney test with significance level $\alpha=0.05$ is obtained significance value (p) of 0.00. It takes a more active research and in a greater scope to conduct more studies in the use of breast milk to use for umbilicard cord of the baby. That requires the active participation of various stakeholders to provide support in implementing it.
\end{abstract}

\section{Keywords}

Umbilical Cord, Breast Milk, Dry Sterile Gauze

\section{Introduction}

Child health problem is one of the main problems in the health sector that is currently happening in the State of 
Indonesia. Degree child health reflects the health of the nation, because children as the future generation have the ability that can be developed in the continuing development of the nation. One indicator of health status in Indonesia is the infant mortality rate. High infant mortality rate in Indonesia is caused by various factors, including the factor of disease, infection and malnutrition. One of the threats to the baby is the occurrence of tetanus. One of the efforts to reduce infant mortality infant care needs to be done properly, especially cord care in order to avoid the risk of infection [1]. Umbilical cord care in general aims to prevent infection and speed up the breakdown of cord [2]. Umbilical cord infection classified as mild strains of the infection but if not treated immediately will be able to develop into a dangerous infection and may even be one of the causes of infant mortality. One medium that is often used by health professionals in the care of the umbilical cord is to use dry Sterile gauze. The media are often used as treatments using umbilical cord dry Sterile gauze proven effective for use in the treatment of the umbilical cord. Average time release of the umbilical cord using a dry Sterile gauze is 154 hours 10 minutes [3]. Recent research conducted one of the ways that can be used for cord care is to use breast milk. Research conducted by Triasih, Widowakti, Haksari and Surjono with the study design Randomize Controlled Trial (RCT) concludes that breastfeeding is safe and effective for the treatment of cord [4]. Most of the people in Indonesia tend to use alcohol as a medium for umbilical cord care. But in reality, umbilical cord care using alcohol tends to take longer than the non-alcoholic cord care. Results of research conducted by Sumaryani [5] show the average time the release of the cord treated with ASI takes 5:32 today, open dry Sterile gauze of 6.65 days and 6.87 days $70 \%$ alcohol.

Infection of the umbilical cord has been the cause of illness and death constantly in different countries. Each year 500,000 infants die from neonatal tetanus and 460,000 infants die from bacterial infections [4]. In the Southeast Asian region, there are an estimated 220,000 infant deaths caused by cord care less clean. According Kasiati [1] long release cord in babies with dry treatment closed more quickly $(70,105) 35$-hour time difference compared to treatment with alcohol. Results of research conducted by the Sri Sumaryani showed the average time of the release of the umbilical cord that was treated with $70 \%$ alcohol 6.87 days/165 hours, open dry takes 6.65 days/159 hours, and by using the ASI takes 5:32 days/127 hours [5]. From the results of the observations made in several BPS in Mojokerto, umbilical cord care were performed using Sterile gauze and alcohol.

Time release umbilical cord is affected by how clean umbilical cord care, humidity cord, environmental sanitation around the newborn, and the incidence of infection of the umbilical cord because of action or treatment that does not meet the requirements of cleanliness Impact umbilical cord care that may result in a release of the umbilical cord is getting slow and umbilical cord infection. Infection of the cord may cause sepsis, menginitis, and others. Fatal risks that may happen are the death in infants [6]. In the tropics, effectiveness of volatile alcohol decreased. Some research which has been done and can't prove the use of alcohol in the care of the umbilical cord is the most effective way [4]. One way that is currently being developed is the use of ASI cord care. In addition to efficient, the use of breast milk as a medium cord care avoids maternal postpartum breast milk of the dams. Besides being able to prevent the mother from the dam breast milk, cord care by using breast milk is much more efficient in economics/finance family because the breast milk in the care of the umbilical cord does not need at all costs or is relatively more economical. The impact of the use of breast milk as a medium cord care is minimal. This is because the content of the milk itself. Various kinds of content of nutrients and substances that exist in breast milk may reduce the risk of incidence of the infection so that the baby can avoid the incidence of umbilical cord infection. Some research which has been done on the effectiveness of treatments using umbilical cord ASI shows that cord care using the ASI has a mean release cord faster than with other media such as dry Sterile gauze, alcohol 70\% and povidone iodine.

The purpose of this study was to compare the effectiveness of treatments umbilical cord using breast milk and dry kassa.

\section{Methods}

This type of research is quasy experiments with static group comparison study design which in practice is used two groups: treatment using breast milk and dry Sterile gauze. The research data obtained by researchers using observation sheet then the data is tabulated. Results of the observation of the time required in the treatment of breast milk and umbilical cord using dry Sterile gauze then compared and conclusions drawn an average release time of each media.

The population in this study is all mothers with infants aged $<1$ month/new mothers and infants, who have living in the Village Sooko Mojokerto. The sample collection technique using total sampling with a sample size 
of 17 people divided into 2 groups. Determine umbilical cord care group using breast milk and cord care using dry Sterile gauze. This obtained 9 babies umbilical cord care was given to breast milk and 8 babies using dry Sterile gauze. The sample in this study is all mothers with newborns in the village Sooko Sooko Mojokerto who met the study criteria were determined researchers, namely:

1) Infants born to normal.

2) Babies who do not have an infection or require special care.

3) Parents of infants who are willing to become respondents in the study.

The research data obtained by researchers using observation sheet then the data is tabulated. Results of the observation of the time required in the treatment of breast milk and umbilical cord using dry Sterile gauze then compared and conclusions drawn an average release time of each media. Long research data release cord care using breast milk and dry Sterile gauze then tabulated for further correlation test Mann-Whitney with significance level $\alpha=0.05$. To facilitate the calculation and reduce the error rate in data analysis, SPSS software used tool for windows 17:00

\section{Ethical Clearance}

Umbilical cord care methods used in this research is to use dry gauze and breast milk. This method selected in order to see the effectiveness of each method of treatment umbilical cord. This study was conducted over a period of 3 months, starting in April 2015 until June 2015. This study was approved by the local ethics commissions are derived from hospital institutions Wahidin Sudiro Husodo mojokerto. This study was approved by the local ethics commissions are derived from hospital institutions Wahidin Sudiro Husodo mojokerto (056/RSU/ EC/II/2015). For the determination of the area used as a study was approved by the Research Commission Mojokerto

\section{Results}

Infants were included in this study did not have an infection or require special care. From Analysis of research data obtained from the data (Table 1): umbilical cord care using Sterile gauze obtained the fastest time of the release cord 151.50 hours; time release of the longest umbilical cord 159.83; average time to release the cord 157.38 and the standard deviation is 3.30. Umbilical cord care using breast milk obtained the fastest time of the release cord 126.83 hours; time release of the longest umbilical cord 128.50; average time to release the cord 127.41 and the standard deviation is 0.50 . From the Mann-Whitney test analysis obtained significance value of 0.001 so the research hypothesis is accepted which means breast milk effective for treatments umbilical cord.

Table 1. Data analisys research.

\begin{tabular}{lll}
\hline & Using breast milk & Using dry Sterile gauze \\
\hline Mean & 127.41 & 157.38 \\
SD & 0.50 & 3.30 \\
Minimum & 126.83 & 151.50 \\
Maximum & 128.50 & 159.83 \\
$\mathrm{~N}$ & 9 & 8 \\
Mann-Whitney U & 0.00 & \\
Wilcoxon W & 45.000 & \\
Z & -3.466 & \\
Asymp. Sig. (2-tailed) & 0.001 & \\
Exact Sig. [2*(1-tailed Sig.)] & $0.000^{\mathrm{a}}$ & \\
\hline
\end{tabular}

Release time measurement results in the baby's umbilical cord.

\section{Discussion}

1) The amount of time required for the baby's cord separated by treated using breast milk.

From the results, the average time of the release of the umbilical cord using breast milk is for 127.41 hours. 
Acceleration of the release cord made possible because the treatment of breast milk contains nutrients found in breast milk can help the healing process.

Stol et al. [5] suggests that effective breastfeeding protects babies against infections and allergies. Breast milk contains substances that are effective in accelerating the release cord. Breast milk contains antibodies, anti-infective, anti-inflammatory and bioactive factor so high that can kill germs in the growth of the baby's body. This opinion is reinforced by Rordan and Auerbach [5] who show that breast milk contains colostrum where in the colostrum itself has a content of protein levels high, especially gamma globulin in order to provide power protection of the body against infection, which have factor of bioactive and contain substances antibodies that can protect infants from infection. Milk in the womb there are a variety of nutrients is very good and suitable for use in the treatment of the umbilical cord. This causes the breast milk is suitable and can be used as one of the media treatment of the umbilical cord in infants. In Handbook of Procedures for the Newborn in Hospital [7] the average time of the release of the umbilical cord with a dry treatment takes 9 days. Average of the time, proving that the breast milk cord care using proven effective for use in the treatment of the baby's umbilical cord.

Umbilical cord care using breast milk a new method in the treatment of the umbilical cord. This is because the content of nutrients in breast milk in the form of lactose, protein, fat and minerals have directly into the cell so that the milk can be used as a medium for cord care. Protein in breast milk that is high enough role in the repair process of damaged cells, accelerate the healing process so as to speed up the release of the umbilical cord. By using the breast milk as a media umbilical cord care, mother and baby will get the most benefit. For mother several benefits such as easy to get the milk and do not need to pay to get media treatment used in the care of the baby. For babies a few benefits gained among babies can avoid the risk of infection due to the content of nutrients in breast milk that can prevent infection and infants can avoid the risk of alaergi use of antibiotics such as alcohol and povidone iodine. By using the breast milk as a media umbilical cord care, make time release of the umbilical cord will be more brief and ensure no infection in infants due to the use of media treatment of the umbilical cord is not suitable for babies.

2) The amount of time required for the baby's cord separated by treated using dry Sterile gauze

From the research, the average time of the release of the umbilical cord using a dry Sterile gauze is for 157.38 hours. Treatments using umbilical cord is often referred to as a dry Sterile gauze care open umbilical cord, cord care covered, wet or cord care. The use of gauze had been believed to be effective and efficient to prevent infection and speed up the breakdown of cord. Basically umbilical cord infection can be prevented by performing cord care is good and right, namely the principles of clean and dry treatments [3].

Most cord care in Indonesia tends to use dry Sterile gauze. This is in addition to effective treatment using umbilical cord dry Sterile gauze also suppresses the incidence of infection of the umbilical cord. This is what makes a dry Sterile gauze is always used as a medium of cord care along with alcohol and povidone iodine. Because of the effectiveness of which has been proven, made largely on infant umbilical cord care using open dry Sterile gauze and make something that is common if treatment is identical to the umbilical cord using a dry Sterile gauze. Dry Sterile gauze is widely used by health workers to perform cord care. This is a culture and practice of science that continues to be done by nearly every health workers, especially midwives and neonatal nurses in the room. This practice is done because the umbilical cord care using dry Sterile gauze to reduce the risk of infection in infants.

3) The effectiveness of treatment using umbilical cord in infants breast milk and dry Sterile gauze

From the results of correlation Mann Whitney test with significance level $\alpha(0.05)$ is obtained significance value (p) of 0.00 . Because the significance value (p) obtained $<\alpha(0.05)$, then the hypothesis in this study received, breast milk effective means for use in the treatment of the baby's umbilical cord.

Breast milk has been only used as baby food and breast milk with the development of science began to be used as a liquid to take care of the umbilical cord in infants because breast milk is considered safe and effective for treatment of the umbilical cord in infants. Breast milk is effectively used as a medium cord care because the nutrients are contained in breast milk itself. Breast milk is protein. Protein serves as forming bonds of essential body, regulate body fluid balance, maintaining the neutralization of the body to react to acidic wet so that PH balanced body, forming antibodies, as well as an important role in transporting nutrients into tissues [5], This opinion is reinforced by the theory put forward (Corwin, 1996) (cited by Sumaryani) which suggests that breast milk contains lymphocytes which consists of two cells, namely B cells and T cells B cells functioning as humoral immunity, immunoglobulin receptors that can recognize foreign antigens and can develop as a antibody-forming plasma cells. $\mathrm{T}$ cells function as helper cells in forming antiodi $\mathrm{B}$, have specific receptors on antigen 
and plays a role in suppressing the immune response. Physiologically when there is a foreign object in the body of $\mathrm{B}$ cells or $\mathrm{T}$ cells will be activated and make a response to makroag against foreign objects, resulting in $\mathrm{B}$ cells and $\mathrm{T}$ cells will proliferate in macrophages and mitotic division occurs. This process makes breastfeeding effectively as a medium that can be used in the treatment of the cord based on the nutrient content and cost efficiency in its use compared with treatment using umbilical cord with dry Sterile gauze. Breast milk contains nutrients that have various kinds such as protein, fat, carbohydrates, minerals and vitamins effective for use as a media cord care in infants.

Research conducted showed the average time of the release of the umbilical cord that was treated using the breast milk is 127 hours 31 minutes, and the mean time of the release of the cord treated using dry Sterile gauze is 159 hours 17 minutes. The results showed that the timing of the release cord taken care of by using the ASI 32 hours 14 minutes faster than the treatment using dry Sterile gauze $(p=0.00)$. According Widowati $(2003$, cited by Sumaryani) excellent nutrient content in the milk, such as lactose, protein, fat, minerals and vitamins in milk, has the effect of directly into the cell. Breast milk contains a high enough protein. Protein function is to form a bond of essential body, regulate body fluid balance, to keep neutralization of the body with a wet acid that reacts to body $\mathrm{pH}$ balanced, forming antibodies, and plays an important role in transporting nutrients to the tissues.

The content of nutrients in breast milk such as fat, carbohydrates, minerals, vitamins, and proteins as well as the composition of breast milk changes every staged as colostrum, transitional breast milk/intermediate, mature breast milk plays an important role in every phase of wound healing in the umbilical cord. The content of nutrients such as colostrum (the formation of antibody/globulin), fat (formation/regeneration of cells), lactobacillus (activating the immune system), lactoferin (inhibits bacterial growth) and carotene (inhibits the growth of bacteria) is indirectly active role in the regeneration of cells and help the wound healing process in the umbilical cord. By using the breast milk as a media cord care, time release cord is needed more quickly, efficiently and in a cost effective and safe for use as an alternative media cord care.

\section{Conclusion}

Umlibilical cord care is an important factor in the future growth and development of infants. This is because as long as umbilical cord care, each baby is at risk of umbilical cord infection and most fatal consequence is the occurrence of death in infants. The use of dry Sterile gauze is a medium that has been used for umbilical cord care. The latest breakthrough in umbilical cord care is using breast milk. In addition to efficient, breast milk is used as a medium umbilical cord care to avoid maternal postpartum breast milk of the dams. Besides being able to prevent the mother from the dam breast milk, cord care by using breast milk is much more efficient in economics/finance family because breast milk in the care of the umbilical cord does not need at all costs or is relatively more economical. The impact of the use of breast milk as a medium cord care is minimal. This is because of the content of the milk itself. Various kinds of content of nutrients and substances that exist in breast milk may reduce the risk of incidence of the infection so that the baby can avoid the incidence of umbilical cord infection.

\section{Acknowledgements}

Technical and scientific support of the study was provided by Department of Nursing, Faculty of Medical Sciences, STIKES Dian Husada, Mojokerto, East Java, Indonesia.

\section{References}

[1] Kasiyati (2009) Comparative Effectiveness Using Umbilical Cord Care ASI, Alcohol 70\% and Povidone Iodine. http://www.digilib.ui.ac.id/

[2] Kartika, S. (2009) Umbilical Cord Care In Toddlers. http://www.inpiredkids.com/care-center-strap-on-balita.htm

[3] Anwar, S. (2008) Activity Alcohol 70\%, 10\% Povidone Iodine, and Kasa Dry Sterile in Infection Prevention in Treatment after Cutting Umbilical Cord Umbilical Cord and Old unscrews in Space Neonatology Section of Child Health DR Zainoel Abidin General Hospital in Banda Aceh. Journal of Dynamics, VI.

[4] Sodikin (2000) Umbilical Cord Care Booklet. EGC, Jakarta.

[5] Sumaryani, S. (2009) Differences in Time Release Cord and Genesis Omphalitis in Umbilical Cord Care with Asi, Alcohol 70\%, and Dry Open. http://www.lontar.ui.ac.id/ 
[6] Admadilaga, B.Y. (2013) Treatment Effectiveness Using ASI Cord Release Cord to Accelerate in Infants Sumberanyar in the Village of Pasuruan. S1 Study Program of Nursing, STIKES Dian Husada, Mojokerto.

[7] The Director General of Medical MOH (2010) Handbook of Procedures Newborn in Hospital. Jakarta. 